\title{
EFFECTS OF OCCUPATIONAL STRESS ON THE ACTIVATION OF HEMOSTATIC AND INFLAMMATORY SYSTEM
}

\author{
Hana Matijaca ${ }^{1}$, Petar Gaćina ${ }^{1}$, Goran Rinčić ${ }^{1}$, Ana Matijaca², \\ Josipa Josipović ${ }^{3}$ and Sanja Stojsavljević ${ }^{4}$
}

\begin{abstract}
${ }^{1}$ Division of Hematology, Department of Internal Medicine, Sestre milosrdnice University Hospital Centre, Zagreb, Croatia; ${ }^{2}$ Division of Endocrinology, Department of Internal Medicine, Dubrava University Hospital, Zagreb, Croatia; ${ }^{3}$ Division of Nephrology, Department of Internal Medicine, Sestre milosrdnice University Hospital Centre, Zagreb, Croatia; ${ }^{4}$ Division of Gastroenterology, Department of Internal Medicine, Sestre milosrdnice University Hospital Centre, Zagreb, Croatia
\end{abstract}

\begin{abstract}
SUMMARY - A 24-hour shift is one of the major stressors for physicians because, apart from causing fatigue and circadian rhythm disorders, it often requires making vital decisions for patients within a short time frame. It is known that workplace stress leads to the activation of the coagulation system, which can result in imbalance of the coagulation and fibrinolysis system. The state of stress can also generate proinflammatory mediators. The aim of this study was to examine the effect of 24-hour shift on global coagulation tests of $\mathrm{D}$-dimers and fibrinolysis, and on C-reactive protein (CRP) as an acute inflammatory agent and proatherosclerotic factor. Sixty physicians (residents) aged 25-35 participated in this study (30 participants in the experimental group and 30 participants in the control group). In experimental group, blood samples were collected on three occasions: shortly before 24hour shift, twelve hours after the shift had begun, and at the end of the shift. Blood samples were collected from control group participants at the same time points. The results showed that there was no statistically significant difference in the values of $\mathrm{D}$-dimer and fibrinolysis between the experimental and control groups. CRP values were statistically significantly higher in the experimental (1.57, 1.49 and 1.50) than in the control group $(0.79,0.75$ and 0.84$)$ on all three measurements $(p=0.024$, $\mathrm{p}=0.020$ and $\mathrm{p}=0.030$, respectively). These results confirmed the existence of proinflammatory changes in the endothelium of blood vessels, which is a factor associated with accelerated atherosclerosis.
\end{abstract}

Key words: Occupational stress; Shift work schedule; Medical staff, hospital; Fibrinolysis; C-reactive protein; Atherosclerosis

\section{Introduction}

Stress can be defined as a situation in which a stressor, or something we perceive as danger, triggers a certain psychobiological response. This response helps the individual deal with an unpredictable situation ${ }^{1}$. One type of stress is occupational stress, which devel-

Correspondence to: Hana Matijaca, $M D$, Division of Hematology, Department of Internal Medicine, Sestre milosrdnice University Hospital Centre, Vinogradska c. 29, HR-10000 Zagreb, Croatia E-mail: hanamatijaca@gmail.com

Received January 31, 2018, accepted May 16, 2018 ops as a result of increased demands and reduced ability to meet the said demands. It occurs when failure to meet these demands leads to significant consequences. A low level of stress can have motivating effects, but too much stress leads to low productivity at work ${ }^{2}$. Night work and shift work are very disruptive to physicians' social lives. They are more often dissatisfied, emotionally exhausted, and show signs of burnout. Disruption of the circadian biological endogenous rhythms has a strong impact on the psychological and physical health of physicians. Long work hours, night shifts, and exposure to stressful working environments 
all correlate with the activation of the hemostatic system. The activation of coagulation cascade has been proven, as well as parallel activation of the fibrinolytic system, with coagulation activating to a greater extent, which results in a hypercoagulable state. A study conducted in 2011 among physicians working in intensive care units showed an increase in serum concentration of tissue factors as a physiological initiator of coagulation. It also showed that its increased levels induced a slightly hypercoagulable state ${ }^{3}$. Exposure to intense psychological and intellectual demands, limited time for making decisions, working at night, and working in shifts all act as stressors and increase the risk of cardiovascular incidents ${ }^{4,5}$. The consequences of cumulative exposure to such a work schedule are not entirely clear, but it is known that they include autonomic dysfunction and neuroendocrine activation. There is also abundant evidence suggesting that shift work increases the risk of coronary heart disease, and that even brief exposure to episodes of mental stress leads to endothelial dysfunction and coagulation activation in healthy individuals ${ }^{6}$. Mediators of the autonomic nervous system activity are stress hormones, primarily noradrenaline and cortisol, which trigger a cascade of inflammatory reactants (interleukin-6, interleukin-1, C-reactive protein (CRP), tumor necrotizing factor alpha, leptin, angiotensin II) causing proinflammatory conditions on the endothelium of blood vessels $\mathrm{s}^{7-9}$.

The aim of this study was to investigate the extent to which stress as a consequence of 24-hour work leads to activation of the coagulation and fibrinolysis system, and whether changes could be detected by routine coagulation tests determining $\mathrm{D}$-dimer values, fibrinolysis and CRP value as an acute inflammatory reactant.

\section{Subjects and Methods}

Participants of the study were physicians (residents) aged 25-35 whose work was periodically organized as 24 -hour shift. There were 60 participants in total, including 30 subjects in experimental group and 30 subjects in control group. Experimental group consisted of 15 women and 15 men. Control group consisted of 19 women and 11 men, physicians of the same ethnic background and age group. The study did not include pregnant women, hormonal contraception users, subjects with a positive history of thromboembolic incidents, nicotinism, acute infectious diseases
(CRP $<5 \mathrm{mg} / \mathrm{L}$ ), body mass index $<18.5$ and $>25 \mathrm{~kg} /$ $\mathrm{m}^{2}$, or physicians who had done their last 24-hour shift less than five days before the experiment began, in order to obtain results based exclusively on acute exposure to stress at work.

\section{Ethics}

Participants were recruited on voluntary basis. All participants signed an informed consent form agreeing to three venipunctures in aseptic conditions performed by the professional medical staff of the hospital. Age and sex were the only personal information recorded. Prior to signing the written consent, each participant was thoroughly informed about the purpose of the study. The study was approved by the Ethics Committee, School of Medicine, University of Zagreb.

Venous blood samples were obtained by venipuncture at the workplace on three occasions. The first sample was collected 15 minutes before the beginning of 24-hour shift. The second sample was collected 12 hours after the shift had begun. The third sample was collected 24 hours after the beginning of the shift, i.e. at the end of the shift. In control group, blood samples were collected at the same time points. Blood was drawn from cubital vein into two VACUETTE $^{\circledR}$ tubes, one for coagulation parameters containing 3.2\% $\mathrm{Na}$-citrate (Greiner Bio-One $\mathrm{GmbH}$, Austria), and the other for CRP (Greiner Bio-One $\mathrm{GmbH}$, Austria). The puncture site had to be disinfected and dried beforehand, while the tourniquet used to increase pressure in the veins in order to increase their visibility was used for less than one minute to prevent hemoconcentration. The vacuum tubes enabled drawing blood directly into the tube by vacuum until the required amount was collected. In the tubes containing $3.2 \% \mathrm{Na}$-citrate, the ratio of blood to anticoagulant was 10:1 (9 parts blood:1 part anticoagulant). The samples collected were used to determine the following parameters: D-dimer level, fibrinolysis and CRP level.

D-dimer concentration was determined using the automated coagulation analyzer Behring Coagulation System-BCSXP with the Innovance D-dimer (Siemens Healthcare Diagnostics, Marburg, Germany) reagent by the immunoturbidimetric method using monoclonal antibodies (covalently bound to polystyrene particles) specific to epitopes on the fibrin D-dimer fragment. The resulting reaction between $\mathrm{D}$-di- 
Table 1. Differences in fibrinolysis, $D$-dimer and $C$-reactive protein (CRP) levels between two study groups (independent t-test)

\begin{tabular}{|c|c|c|c|c|c|c|c|c|c|c|c|}
\hline & \multicolumn{10}{|c|}{ Group } & \multirow{3}{*}{$p$} \\
\hline & \multicolumn{5}{|c|}{$\begin{array}{l}\text { On call }(24 \mathrm{~h}) \\
\mathrm{N}=30\end{array}$} & \multicolumn{5}{|c|}{$\begin{array}{l}\text { 8-hour working shifts } \\
\mathrm{N}=30\end{array}$} & \\
\hline & \multirow{2}{*}{\begin{tabular}{|l|} 
Mean \\
172.00
\end{tabular}} & \multirow{2}{*}{\begin{tabular}{|l|}
$S D$ \\
43.10
\end{tabular}} & \multirow{2}{*}{$\begin{array}{l}\text { Median } \\
185.00\end{array}$} & \multicolumn{2}{|c|}{$\begin{array}{l}95.0 \% \mathrm{CI} \\
\text { for median }\end{array}$} & \multirow{2}{*}{\begin{tabular}{|l|} 
Mean \\
185.50
\end{tabular}} & \multirow{2}{*}{\begin{tabular}{|l} 
SD \\
37.65
\end{tabular}} & \multirow{2}{*}{\begin{tabular}{|l|} 
Median \\
200.00
\end{tabular}} & \multicolumn{2}{|c|}{$\begin{array}{l}95.0 \% \mathrm{CI} \\
\text { for median }\end{array}$} & \\
\hline Fibrinolysis $0 \mathrm{~h}$ & & & & 140.00 & 210.00 & & & & 200.00 & 210.00 & 0.149 \\
\hline Fibrinolysis $12 \mathrm{~h}$ & 127.33 & 39.56 & 120.00 & 120.00 & 150.00 & 144.33 & 37.41 & 150.00 & 150.00 & 190.00 & 0.214 \\
\hline Fibrinolysis $24 \mathrm{~h}$ & 175.33 & 51.78 & 210.00 & 210.00 & 210.00 & 168.83 & 51.34 & 205.00 & 135.00 & 210.00 & 0.698 \\
\hline D-dimers $0 \mathrm{~h}$ & 0.35 & 0.42 & 0.24 & 0.19 & 0.30 & 0.36 & 0.21 & 0.30 & 0.26 & 0.42 & 0.463 \\
\hline D-dimers $12 \mathrm{~h}$ & 0.31 & 0.36 & 0.20 & 0.17 & 0.28 & 0.31 & 0.19 & 0.26 & 0.20 & 0.33 & 0.573 \\
\hline D-dimers $24 \mathrm{~h}$ & 0.29 & 0.30 & 0.18 & 0.17 & 0.28 & 0.36 & 0.24 & 0.31 & 0.27 & 0.38 & 0.965 \\
\hline CRP $0 \mathrm{~h}$ & 1.57 & 1.64 & 0.95 & 0.50 & 1.60 & 0.79 & 0.72 & 0.55 & 0.40 & 0.80 & 0.024 \\
\hline CRP $12 \mathrm{~h}$ & 1.49 & 1.63 & 0.95 & 0.40 & 1.60 & 0.75 & 0.69 & 0.50 & 0.40 & 0.90 & 0.020 \\
\hline CRP $24 \mathrm{~h}$ & 1.50 & 1.57 & 0.75 & 0.40 & 1.70 & 0.84 & 0.63 & 0.65 & 0.50 & 0.90 & 0.030 \\
\hline
\end{tabular}

mer in plasma and monoclonal antibodies is detected turbidimetrically, with an increase of adsorption at 405 $\mathrm{nm}$ proportional to the concentration of D-dimer in the plasma sample. Normal D-dimer values are $\leq 0.5$ $\mathrm{mg} / \mathrm{mL}$.

The fibrinolysis-euglobulin test is a non-automated method of macroscopic detection of clot lysis. Nine $\mathrm{mL}$ of distilled water, $100 \mu \mathrm{L}$ of $1 \%$ acetic acid and $500 \mu \mathrm{L}$ of sample is pippeted into a $10-\mathrm{mL}$ test tube. The tube is gently mixed and put in the refrigerator for 30 minutes to form a precipitate, i.e. euglobulin fraction that contains the plasminogen activator, plasminogen, plasminogen activator inhibitor-1 (PAI-1) and fibrinogen. After centrifugation for 10 minutes at $4000 \mathrm{rpm}$, the supernatant is discarded and the tube with the remaining content is put in reverse position on the stack for 5 minutes. The tube is then transferred to water bath at $37^{\circ} \mathrm{C}$, to which $500 \mu \mathrm{L}$ of borate buffer is added to dissolve the precipitate rich in fibrinolytic components, and $500 \mu \mathrm{L} \mathrm{CaCl} 2$ is added to deposit fibrinogen and form a clot. The clamping time is recorded every 15 minutes and the clot lysis time is observed using a macroscope. The result is expressed as time in minutes, where complete lysis of the precipitate is determined by macroscopic examination, i.e. when it becomes transparent instead of milky white. Normal fibrinolysis takes between 180 and 210 minutes.
The level of CRP was determined on an automated, multi-channel, selective analyzer Architect c8000 (Abbott, USA). The analytical method is based on the reaction between CRP and anti-CRP antibodies bound to latex particle reagent, resulting in optimal sensitivity. Normal CRP concentration is $<5 \mathrm{mg} / \mathrm{L}$.

\section{Statistical methods}

The data obtained were presented in tables and graphs. All continuous data were expressed by means with corresponding standard deviations and medians with corresponding 95\% confidence intervals (95\% CI). Differences between the groups in fibrinolysis, Ddimer and CRP levels at each measuring time were assessed by independent t-tests. ANOVA for repeated measures with within-between interactions was used to analyze differences in dynamics between the groups and according to time of measurement. Estimated marginal means with 95\% CI were calculated. All p values below 0.05 were considered significant. The IBM SPSS Statistics version 24 was used in all statistical procedures.

\section{Results}

Differences between the two study groups according to fibrinolysis, D-dimer and CRP levels are shown in Table 1. There were no significant differences in fi- 

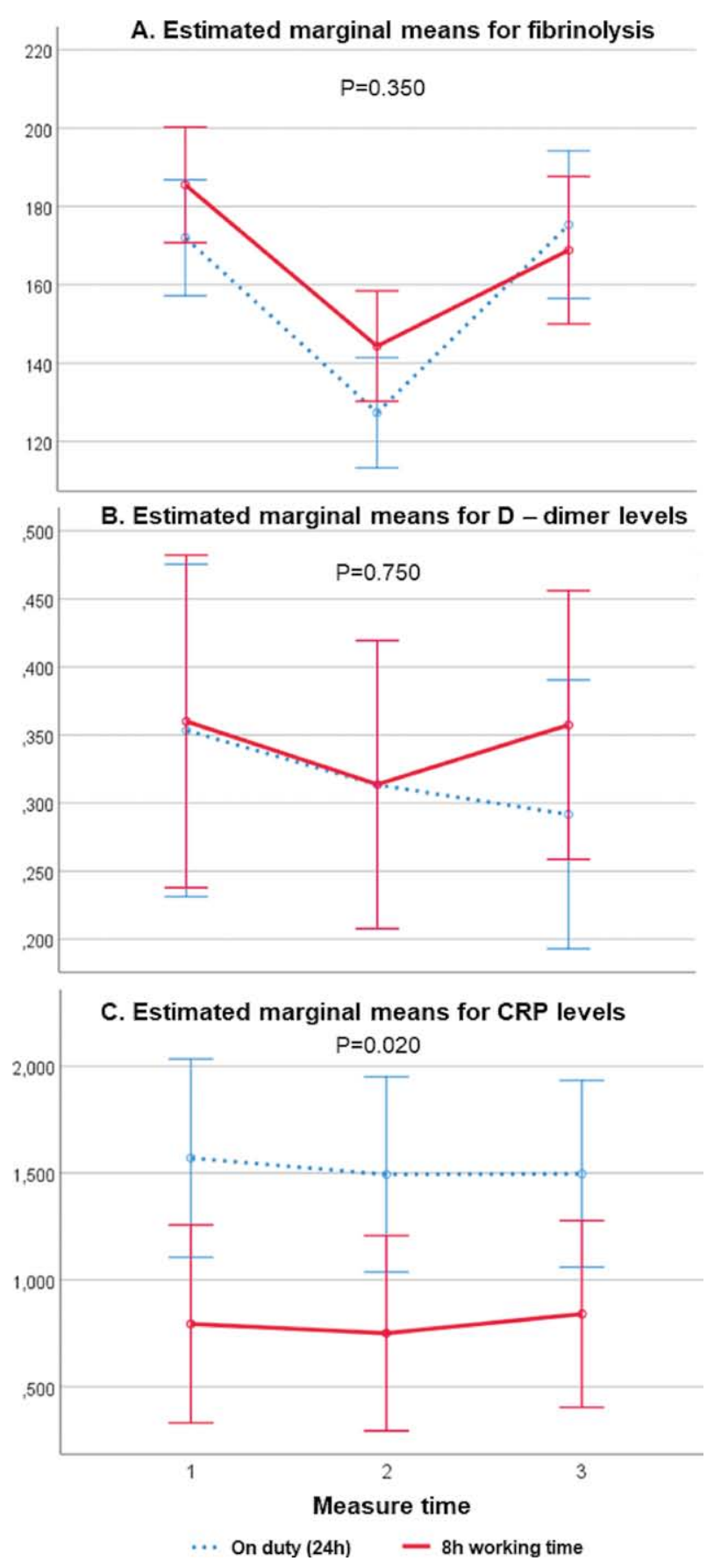

Fig. 1. Differences in the dynamics of fibrinolysis, $D$-dimer and $C$-reactive protein (CRP) levels between study groups (repeated measures ANOVA).

brinolysis and D-dimer levels, while CRP levels were significantly higher in the group having completed a 24-hour shift as compared with the group having completed an 8-hour shift (1.57, 1.49 and 1.50 vs.
$0.79,0.75$ and $0.84 ; \mathrm{p}=0.024, \mathrm{p}=0.020$ and $\mathrm{p}=0.030$, respectively).

Differences in fibrinolysis, D-dimer and CRP level dynamics between the investigated groups are shown in Figure 1. There were no significant differences in dynamics between the groups in any of the three parameters. However, when looking at the average estimated means for all three measures, CRP level was significantly higher in the 24-hour shift group as compared to the group that worked an 8-hour shift (1.52, 95\% CI 1.07-1.96 vs. 0.79, 95\% CI 0.35-1.24, respectively; $\mathrm{p}=0.020$ ).

\section{Discussion}

Twenty-four hour shifts are physically demanding for physicians due to the lack of rest and sleep. They are also accompanied by great psychological burden of responsibility for patients, urgent diagnostics and therapy, and the need to make decisions that are often of vital importance for patient health. A study conducted by Tür et al. showed that doctors with various specializations working night shifts often faced stress. This study also showed that younger physicians were often under greater stress than their older colleagues, which was expected due to their lack of experience ${ }^{10}$.

Our study included young residents aged 25-35. Opting for a narrow age gap meant we could avoid the influence of age-related defects on coagulation parameters and reactants of acute inflammation ${ }^{11}$. In this work, the dynamics of fibrinolysis, D-dimer and CRP values in the experimental group of physicians was determined at the beginning of shift (8 a.m.), halfway through (after 12 h, 8 p.m.), and at the end of shift (after 24 h, 8 a.m. on the next day). The same parameters were determined at the same time intervals in the control group. The results obtained showed no statistically significant differences in D-dimer concentration and fibrinolysis between the experimental and control groups, whereas CRP level showed statistically significant differences at all time points of measurement.

$\mathrm{C}$-reactive protein is a protein with a ring-like structure. Its concentration is an indicator of inflammatory events in the body. It is synthesized in hepatocytes and degraded by macrophages. CRP level is increased in blood as a result of various factors, e.g., sleep disturbances, smoking, stress, socioeconomic factors, and extreme cold. Hormones/pathways that increase 
CRP are cytokines IL- 6, IL-1 $\beta$, IL-17, TNF- $\alpha$ and leptin. Lifestyles that lead to decreased CRP include exercise, weight loss, balanced diet, moderate intake of alcohol, sexual activity, and optimism. The normal CRP levels vary among populations, with mean values from under 1.0 up to $3.0 \mathrm{mg} / \mathrm{L}$. Our research included only those participants with CRP levels up to $5 \mathrm{mg} / \mathrm{L}$, thus excluding the possibility of acute infections.

In all three measurements, CRP levels showed statistically significantly higher values in the 24-hour shift group. Since 24-hour shift presupposes increased mental and physical tension, sleepless nights and exhaustion, the results obtained in our work correspond to the present understanding of the impact of stress on $\mathrm{CRP}^{12}$. Furthermore, this research demonstrated that the higher level of this parameter in the experimental group was present throughout the 24-hour shift. The CRP values in all three measurements showed statistically significantly higher value in the experimental group compared to the control group. Statistically significantly elevated CRP values in the first measurement in the experimental group could be explained by the fact that psychological preparation for 24-hour shift was present for a definite period of time before the beginning of the shift. In both groups, CRP showed constant values in all three measurements, which was expected, since the half-life of this protein is around 19 hours. This also explains the statistically significant difference in the last measurement in the experimental group because on 24-hour shift, there was not enough time to lower the value to the level observed among physicians in the control group.

$\mathrm{C}$-reactive protein is not just a systemic inflammatory marker. It is also a local pro-atherosclerotic factor. It can cause hardening of arteries ${ }^{13}$. CRP has proinflammatory effects on blood vessel cells and may play a causal role in the pathogenesis of heart artery disease ${ }^{14}$. It can activate the cells that line the interior of blood vessels, and can cause their dysfunction. CRP reduces nitric oxide (NO) release from arterial and venous cells. NO is important because it relaxes narrowed blood vessels, and increases oxygen and blood flow ${ }^{15}$.

From the afore-mentioned data, it can be concluded that the physicians from the experimental group were at a greater risk of developing atherosclerosis and all accompanying complications, including cardiovascular and cerebrovascular incidents. A study which examined the connection between exposure to current and cumulative night shift work and subclinical parameters of atherosclerosis showed significantly increased arterial stiffness, resulting in flow velocity increase for individuals with night shifts compared to non-night workers ${ }^{16}$. A conclusion drawn in the clinical review that summarizes the material available on shift work and how it relates to chronic diseases, insufficient sleep and accidents, is that shift work, including night shift work, can be linked to an increased risk of coronary heart disease (myocardial infarction), ischemic stroke, type 2 diabetes, obesity/weight gain, breast cancer, prostate cancer and colorectal cancer ${ }^{17}$.

Fibrinolysis is a process that involves degradation of the clot formed in blood vessels. During the fibrinolysis process, the fibrin mesh, which is an important factor in clot formation, is cleaved by plasmin, wherein smaller parts are removed by kidney and liver protease activity. Fibrinolysis is expressed in minutes. Coagulation and fibrinolysis work together to ensure optimal functioning of blood flow and to repair vessel wall lesions. In many healthy individuals, coagulation and fibrinolysis are activated simultaneously as a response to acute mental stress, with the balance shifted towards procoagulant milieu. From an evolutionary standpoint, the procoagulant response is biologically sensible in that it may protect the body from the potential blood loss in a fight-or-flight situation ${ }^{18}$. Many years ago, it was discovered that fibrinolytic activity in blood showed a sinusoidal variation within 24 hours; it increased substantially during the day, peaking at 6:00 p.m., and then dropped to trough levels at 3:00-4:00 a.m. In our study, fibrinolysis in second measurement (at 8 p.m.) was shorter in both groups, corresponding to the circadian rhythm. Increased fibrinolytic activity and shorter fibrinolysis in the late afternoon resulted in faster clot degradation. There was no statistically significant difference in fibrinolysis between the experimental and control groups. In the first measurement, fibrinolysis was shorter in experimental group compared to control group, which was expected considering psychological preparation for 24-hour shift. In the second measurement, fibrinolysis was shorter compared to the first measurement in both groups, corresponding to the circadian rhythm. In the third measurement, inversion in fibrinolysis duration was observed. After 24-hour shift, fibrinolysis was longer than in the control group. This could indicate strain of defense mechanisms in the body. These facts were not 
corroborated by statistical significance, which opens and expands the possibilities for further research.

D-dimer was originally described in the 1970s and found diagnostic application in the 1990s. The D-dimer antigen is a unique marker of fibrin degradation that is formed by the sequential action of three enzymes, i.e. thrombin, factor XIIIa and plasmin. It is a small protein fragment present in the blood after a blood clot has been degraded by fibrinolysis. It is named $\mathrm{D}$-dimer because it contains two $\mathrm{D}$ fragments of the fibrin protein joined by a cross-link ${ }^{19}$. In this study, the values of $\mathrm{D}$-dimer were the same in the first and second measurements in both experimental and control groups, with a note that in the second measurement, the value of $\mathrm{D}$-dimer was lowered in both groups. In the third measurement, further reduction of D-dimer values was observed in experimental group, while in control group the values recovered to the level recorded in the first measurement. It could be concluded that the lowered D-dimer values in the last measurement in the experimental group fit the abovementioned data on prolonged fibrinolysis at the end of 24-hour shift, i.e. in the third measurement in the participants having worked the night shift. The prolonged fibrinolysis indicates a long time for blood clot degradation, which changes the hemostatic system balance to hypercoagulability. Other authors' findings suggest an attenuated immediate $\mathrm{D}$-dimer stress response and delayed recovery of $\mathrm{D}$-dimer levels post-stress. In particular, the prolonged hypercoagulability after stress cessation might contribute to the atherothrombotic risk previously observed with vital exhaustion, even at subclinical levels ${ }^{20}$.

Hospital physicians were included in the present study. They have to make decisions that directly affect their patients' health, and very often their lives. They are under pressure due to urgency of decision-making and a large number of patients. In this work, no statistically significant differences were found in coagulation parameters (D-dimers and fibrinolysis) between the two groups, however, a statistically significantly higher CRP value was verified through all three measurements in the experimental group. It was previously indicated that CRP is a pro-atherosclerotic indicator.

We believe that further research is needed due to the very stressful work of physicians. Thus, better insight could be gained concerning the risk of developing thromboembolic incidents and cardiovascular dis- eases. These results could affect the possible reorganization of work in 24-hour shifts and introduction of more frequent preventive health check ups, along with determination of more useful biochemical indicators of stress-induced changes.

\section{References}

1. McVicar A, Ravalier JM, Greenwood C. Biology of stress revisited: intracellular mechanisms and the conceptualization of stress. Stress Health. 2014 Oct;30(4):272-9. doi: 10.1002/smi. 2508. Epub 2013 Jul 19.

2. Knežević B, Golubić R, Milošević M, Matec L, Mustajbegović J. Zdravstveni djelatnici u bolnicama i stres na radu: istraživanje u Zagrebu. Sigurnost. 2009 July;51(2):85-92. (in Croatian)

3. Matejovic M, Chvojka J, Sykora R, Krouzecky A, Radej J, Parizkova $\mathrm{R}$, et al. A 24-h work shift in intensive care personnel: biological pathways between work stress and ill health. J Int Med Res. 2011;39: 629-36. doi: 10.1177/147323001103900232.

4. Vrijkotte TG, van Doornen LJ, de Geus EJ. Work stress and metabolic and hemostatic risk factors. Psychosom Med. 1999 Nov-Dec;61(6):796-805. PubMed PMID:10593631.

5. von Känel R, Mills PJ, Fainman C, Dimsdale JE. Effects of psychological stress and psychiatric disorders on blood coagulation and fibrinolysis: a biobehavioral pathway to coronary artery disease? Psychosom Med. 2001 Jul-Aug;63(4):531-44. PubMed PMID:11485106.

6. von Känel R, Frey K, Fischer JE. Independent relation of vital exhaustion and inflammation to fibrinolysis in apparently healthy subjects. Scand Cardiovasc J. 2004;38(1):28-32. Available from: https://doi.org/10.1080/14017430310015884.

7. Jankord R, Zhang R, Flak JN, Solomon MB, Albertz J, Herman JP. Stress activation of IL-6 neurons in the hypothalamus. Am J Physiol Regul Integr Comp Physiol. 2010 Jul;299(1): R343-51.Epub 2010 Apr 28. doi: 10.1152/ajpregu.00131.2010. PubMed PMID: 20427720; PubMedCentral PMCID: PMC 2904148.

8. Koelsch S, Boehlig A, Hohenadel M, Nitsche I, Bauer K, Sack $\mathrm{U}$. The impact of acute stress on hormones and cytokines, and how their recovery is affected by music-evoked positive mood. Scientific Reports 6, Article number: 23008 (2016). doi: 10.1038/srep23008.

9. Slavish DC, Graham-Engeland JE, Smyth JM, Engeland CG. Salivary markers of inflammation in response to acute stress. Brain Behav Immun. 2015 Feb;44:253-69. Available from: https://doi.org/10.1016/j.bbi.2014.08.008

10. Tür FÇ, Toker İ, Şaşmaz CT, Hacar S, Türe B. Occupational stress experienced by residents and faculty physicians on night shifts. Scand J Trauma Resusc Emerg Med. 2016 Mar 22;24:34. doi: 10.1186/s13049-016-0225-4. PubMed PMID:27000300; PubMed Central PMCID:PMC4802727. 
11. Wirtz PH, Redwine LS, Baertschi C, Spillmann M, Ehlert U, von Känel R. Coagulation activity before and after acute psychosocial stress increases with age. Psychosom Med. 2008 May;70(4):476-81. doi: 10.1097/PSY.0b013e31816e03a5.Pub MedPMID:18480193.

12. Johnson TV, Abbasi A, Master VA. Systematic review of the evidence of a relationship between chronic psychosocial stress and C-reactive protein. Mol Diagn Ther. 2013 Jun;17(3): 147-64. doi: 10.1007/s40291-013-0026-7. PubMed PMID: 23615944.

13. Montecucco F, Mach F. New evidences for C-reactive protein (CRP) deposits in the arterial intima as a cardiovascular risk factor. Clin Interv Aging. 2008 Jun;3(2):341-9. PubMed PMID: 18686755; PubMed CentralPMCID: PMC2546477.

14. Stancel N, Chen CC, Ke LY, Chu CS, Lu J, Sawamura T, et al. Interplay between CRP, atherogenic LDL, and LOX-1 and its potential role in the pathogenesis of atherosclerosis. Clin Chem. 2016 Feb;62(2):320-7. doi: 10.1373/clinchem.2015. 243923. Epub 2015 Nov 25.PubMed PMID:26607724.

15. Devaraj S, Siegel D, Jialal I. Statin therapy in metabolic syndrome and hypertension Post-JUPITER: What is the value of
CRP? Curr Atheroscler Rep. 2011 Feb;13(1):31-42. doi: 10.1007/s11883-010-0143-2. PubMed PMID:21046291; Pub Med Central PMCID: PMC3018293.

16. Jankowiak S, Backe E, Liebers F, Schulz A, Hegewald J, Garthus-Niegel S, et al. Current and cummulative night shift work and subclinical atherosclerosis: results of the Gutenberg Health Study. Int Arch Occup Environ Health. 2016;89:1169-82. doi: 10.1007/s00420-016-1150-6.

17. Kecklund G, Axellson J. Health consequences of shift work and insufficient sleep. Clinical review. BMJ. 2016;355:i5210.

18. Hjemdahl P, von Kanel R. Hemostatic effects of stress. In: Hjendahl P, Rosengren A, Steptoe A, editors. Stress and Cardiovascular Disease. London, England: Springer, 2012; p. 89-110.

19. Adam SS, Key NS, Greenberg CS. D-dimer antigen: current concepts and future prospects. Blood 2009;113(13):2878-87. doi: https://doi.org/10.1182/blood-2008-06-165845.

20. von Känel R, Bellingrath S, Kudielka BM. Association of vital exhaustion and depressive symptoms with changes in fibrin D-dimer to acute psychosocial stress. J Psychosom Res. 2009 July;67(1):93-101. doi:https://doi.org/10.1016/j.jpsychores.2008.12.009

Sažetak

\section{POVEZANOST STRESA NA RADNOM MJESTU S AKTIVACIJOM SUSTAVA HEMOSTAZE I UPALE}

\section{H. Matijaca, P. Gaćina, G. Rinčić, A. Matijaca, J. Josipović i S. Stojsavljević}

U ovom istraživanju ispitivan je učinak stresa tijekom produljenog radnog vremena (24-satno dežurstvo) kod mladih liječnika na specijalističkom usavršavanju na aktivaciju sustava hemostaze i upale te mogu li se promjene otkriti osnovnim koagulacijskim testovima mjereći vrijednosti D-dimera i vrijeme fibrinolize te određivanjem razine C-reaktivnog proteina (CRP) kao akutnog reaktanta upale i proaterosklerotskog čimbenika. Dežurstvo kroz 24 sata jedan je od većih stresora za liječnike, jer uz umor i poremećaj cirkadijalnog ritma uključuje odgovornost u donošenju često vitalnih odluka za bolesnike u kratkom roku. Poznato je da stres na radnom mjestu dovodi do aktivacije koagulacijskog sustava, što može rezultirati neravnotežom sustava koagulacije i fibrinolize. Također u stanju stresa dolazi do stvaranja proupalnih medijatora. Cilj ovoga rada bio je ispitati utjecaj 24-satnog dežurstva na globalne koagulacijske parametre D-dimere i vrijeme fibrinolize te na CRP kao akutni reaktant upale i proaterosklerotski čimbenik. Istraživanje je provedeno u 60 liječnika na specijalističkom usavršavanju u dobi od 25 do 35 godina (30 liječnika kojima je rad povremeno organiziran u obliku 24-satnog dežurstva i 30 liječnika u kontrolnoj skupini). Liječnicima je krv uzeta tri puta: neposredno prije dežurstva, nakon 12 sati te na kraju 24-satnog dežurstva. Liječnicima u kontrolnoj skupini su uzeti uzorci krvi u istim vremenskim točkama. Rezultati su pokazali da nije bilo statistički značajne razlike u vrijednostima D-dimera i trajanju fibrinolize između ispitivane i kontrolne skupine. Međutim, pokazalo se da je vrijednost CRP-a statistički značajno viša u ispitivanoj $(1,57 ; 1,49 ; 1,50)$ nego u kontrolnoj skupini $(0,79 ; 0,75 ; 0,84)$ u sva tri mjerenja $(p=0,024 ; p=0,020 ; p=0,030)$. Navedeno potvrđuje postojanje proupalnih promjena na endotelu krvnih žila, što je čimbenik razvoja ubrzane ateroskleroze.

Ključne riječi: Stres na radnom mjestu; Rad u smjenama; Medicinsko osoblje, bolničko; Fibrinoliza; C-reaktivni protein; Ateroskleroza 